\title{
Art Educational Puzzles and their Motivated Role During Homeschooling for People of Determination in Light of COVID-19 Pandemic
}

\author{
Dr. Shereen Mahmoud Raouf Abd Ellatif Mahmoud ${ }^{a}$
}

Lecturer of Child and Adult's Arts Analysis, Art Education Department, Alexandria University, Alexandria, Egypt

\begin{abstract}
every category of society has common characteristics, whether social, psychological or cultural, and through identification of these common characteristics, let us to design programs for them in order to develop their skills, intelligences and to achieve the maximum benefit possible, And the best results of the educational process, so we have to design educational puzzles that bring together under its umbrella many important groups in our society (people of determination), such as visually impaired, hard of hearing, autism, simple mental retardation, etc. in order to develop their arts skills, the consequent expansion of their perceptions, developing some sensory aspects for them and helping them to achieve the maximum that they can reach for compatibility with their physically healthy peers within periods of home schooling during COVID-19 pandemic and includes the implementation of art puzzles to achieve fun and learning together, art educational puzzles teaching children some basic skills like creating various scenes of different shapes, knowing of color circle, the results of combining those colors together, knowing how to distinguish between sizes, learning the artistic motifs concept, and practicing some artistic fields such as printing and simple weaving, to enable them to control the hand muscles synergizing with mind orders.
\end{abstract}

\section{KEYWORDS:}

Art - Puzzles - Motivation - Homeschooling - People of Determination - COVID-19.

\section{INTRODUCTION:}

All peoples recognize the different culture and identity of the role of play in the upbringing of the child, so the child plays with his hands, feet and fingers, then plays with toys or different games such as cars or brides of different sexes and also finds pleasure by putting his hands in colors and papers, so he feels amused and enjoyable, so the rules and games that the child practices develop and the analogy of his intelligence through stages Its development from the phase of sensory-kinesthetic intelligence through symbolic intelligence and scientific intelligence to 
contemplative intelligence, and this diversity in playing patterns and their development helps him to interact with the world around him and helps him in psychological, physical and mental development as well as improving his adaptation to society.

Therefore, the types of games vary according to the age and mental stage of the child and also differ according to the desired goal, so comes the puzzle games varied with multi design as well as various degree of difficulty to achieve its goal accurately, though this research is concerned with the study of puzzles to develop the artistic side of the child and also the development of some skills synchronized with the development of the artistic side, these games are not only for fun and entertainment, but also dominated by other educational goals without That the child feels this to feel a sense of pleasure and entertainment while he is learning and acquiring the skills that his mind and body need. Therefore, studies in the field of children play have unanimously agreed that play is a motive for innovation, learning and acquiring skills, and that the child's innovation and learning can be measured through its production.

This study is concerned with designing and implementing games to stimulate the learning motivation through puzzles for the art fields of some groups of children of determination that are able to learn. Striving in the 21st century, led by the Arab Republic of Egypt, to develop this group of children mentally, physically and psychologically, and to integrate them with their peers from children of the same age as possible so that they become influential members of society seeking to advance it and achieve its goals.

Home education is a type of ancient education that has been developed and introduced, such as the introduction of technological means, the Internet, and various means of communication to become more effective in light of global conditions such as COVID-19 pandemic and the scientific acceleration that occurs throughout the world. There is no room for stopping and waiting for crises to pass by themselves, but we must challenge them and precede them with science and knowledge. And development in all fields.

Hence the questions that motivate this research as follows:

- What is the possibility of art educational puzzles to stimulate the motivation of education at home for children of determination who are able to learn in light of COVID-19 pandemic?

- What is the possibility of designing and implementing educational and artistic puzzles to instill some of simple arts concepts and develop the skills associated 
with them for children of determination who are able to learn?

\subsection{Research problem}

There is no doubt that we are in an era of rapid and continuous progress, no one of the peoples or a generation of generations, can marginalize or exclude an education in light of this acceleration and the challenges that this era faces, and these challenges carry within them, the challenge of education in the light of COVID-19 pandemic is for all children of society, of all ages and also their mental levels, so the burden has become focused on the self-efforts of the child and the family with him, and although these burdens face all families in our society now that have a child of special need of people of determination, he suffers from problems greater than any other families. Therefore, it is incumbent upon us and every officer in the field of science and learning to search and find efforts to overcome the difficulties that face these families, and through my field of research I see that artistic puzzles can facilitate and strengthen the educational motivation of children of determination and also facilitate the educational process for families. In light of the global pandemic that the world is going through today, which is COVID-19 pandemic.

\section{2. research aims}

- Learn the concept of artistic puzzles.

- Providing the opportunity to discover the importance of puzzles in the educational process for certain categories of children of determination.

- Providing suggested solutions for how to stimulate the motivation for education at home for some groups of children of determination.

- Identify some of simple art concepts that can be taught to a child who can learn from people of determination.

- Providing solutions to face some of the difficulties faced by families of children of determination in education at home in light of COVID-19 pandemic.

- Giving ideas about how to provide a child of determination with some special skills in puzzles games, such as the ability to focus and control the muscles of the hand and its synergy with the mind orders.

\section{3. research importance}

- Shedding light on the importance of education during global disasters and pandemics.

- Emphasizing the effectiveness of games in various fields during homeschooling. 
- bring attention to certain categories which need better care, guidance and support, and this in turn helps uplifting society and progress towards a better future.

- Contributing to opening up horizons of thought in the field of artistic games in particular and educational games in general to create new ideas that provide an opportunity for all segments of society to learn through playing and having fun.

\section{4. $\underline{\text { Research Methodology }}$}

The current research follows the analytical approach in the theoretical side and the experimental approach when designing and implementing art educational puzzles to stimulate the homeschooling motivation for certain categories of children of determination.

\subsection{Research Procedural Definitions:}

- Art educational puzzles: They are educational aids in the form of games based on their formation on two main principles, namely segmentation to cut and assemble it again, it contains in its idea a formative arts information that nourishes the mind of the player (the learner).

- Homeschooling: It is one of the education systems that are used in different countries, including the Arab Republic of Egypt, and this educational system appeared in the seventies of the last century in multiple forms, for example, if the learner is enrolled in an educational institution, but he receives his lessons from home according to the curriculum established by this institution and is called a common term. (Homes Education), or it is not restricted to an educational institution, but it learns through the mode of free education curriculum, and there are several different approaches to this free education system, or through remote electronic courses, which is called (E-learning), which has recently spread widely as a result of technological progress and the availability of the Internet everywhere, so there are many forms of homeschooling, which shares a basic point of agreement between them, which is learning from home without the need to go to another place to learn.

- People of Determination: It is a term developed in recent times that means those with great energies that they exert in order to naturally fit into society like the rest of their peers of the same age, so this term is applied to groups that need special care or groups that suffer from deficiencies in any aspect of life, whether physical, social, psychological or Mindset and thus causes problems with communication, learning, and the practice of life in general. 
- COVID-19 Pandemic: It is a global spread of a viral epidemic and scientifically called (COVID-19) spread globally in late 2019, specifically in December, as most scientists expected, which led to a transformation of the aspects of life in general and education in particular.

First: The theoretical study of the research includes two main axes, which are as follows:

- The first axis: educational games, including art puzzles.

- The second axis: Stimulating motivation for homeschooling for children of determination in light of the challenges of the Corona pandemic.

Second: The applied study includes the following research:

Design and implementation of games to stimulate homeschooling for children of determination from a set of puzzles that aim to develop some simple art and motor skills and provide the child with some simplified concepts of various artistic fields.

The following is an explanation and analysis of the theoretical axes:

\subsection{The first axis: educational games, including art puzzles.}

\subsubsection{Concept of play:}

Caveiro (1998) defines it as an activity in which children explore and explore the sounds, colors, shapes, sizes and textures of things through two or three dimensions, where children demonstrate their growing abilities to imagine, listen, observe, use tools, materials and other sources, to express their ideas and communicate with their feelings. also, with others. ${ }^{(1)}$

\subsubsection{Concept of educational games:}

Zaid Al-Huwaidi defines educational games as a purposeful activity that includes actions taken by a child or a group of children to achieve desired goals in their various cognitive, psychomotor and emotional fields.

Educational games are a form of intended directed games according to their own plans, programs, tools, supplies, and educators prepare, try and codify them, then direct children to

(1) Cagier, J. (1998). Communication power for individuals with autism. Focus on Autism and Other Developmental Disabilities, 13 (2), 113-121. 
practice them to achieve specific goals. Educational games can be divided into games that depend on sensory things, also, games that depend on thinking. ${ }^{(1)}$

Educational games are an activity or organized activity, which the child practices alone or in group to achieve a specific goal. ${ }^{(2)}$

It can be said that educational games are activities that are not only intended to entertain or fill the void, but also to help students learn and achieve specific educational goals through positive practice and participation.

It was also defined as a kind of well-framed activities that have a set of laws that regulate the course of play, and in which two or more students usually participate to reach level that achieves goal of the game.

\subsubsection{It is possible to extract a set of different data emanating from the previous concepts, the most prominent of which are:}

- Educational games are kind of purposeful activities.

- The educational games are subject to specific rules and laws.

- Those educational games may include more than one level that interconnect and overlap with each other.

- Educational games focus on interaction and competition between participants through group games.

- Those educational games should end with a specific result for the player who either achieves its goal by completing the game or fails to complete it.

1.6.4. Types of educational games: The types of educational games can be classified according to several classifications:

\section{First: In terms of the place of play, it is divided into:}

- Inside games Children practice it inside the halls and activity rooms, and it is either individual or group.

- Outside games: Backyard games are free and directed games that children can play outside of the activity room. ${ }^{(3)}$

(1) Zaid Howaidy $2008 \mathrm{M}$ : the games Pedagogical (strategy to develop Thinking), Dar: house the book Undergraduate, UAE Arabic United, s2.

(2) bulqees Ahmad, marie tawfeek, pasture reconcile 2010 M: (Facilitator at Psychology Play (, edition 4, Dar: house The Criterion, Amman, p. 67.

(3) Zaid Howaidy 2008 M: The aforementioned reference, p. 57. 


\section{Second: In terms of the goal's spontaneity, it is divided into:}

- Spontaneous games: They represent the elementary forms of play, so they are not defined by organizing rules for playing, most of them are individual. The child plays whenever he wants, also stops when he is not interested in it, most of the games of this type are exploratory.

- Role-playing games: This type of games depends on children's broad imagination and creative abilities. In it, children imitate the human and material life models surrounding them, and in which the child is affected by a life model from the surrounding environment.

- Delusional games: One of the most common games in the early childhood world, and it is also one of the popular games, in which the child deals with materials or situations as if they have more characteristics than they are in reality, such as playing with the doll as a human being.

- Exploratory games: This type of game includes every process that a child makes to find out the structural components of a thing and how that thing works, such as a child playing with cooking tools.

\section{Third: In terms of its directed educational goals, it is divided into:}

- Recreational and sports games: This type includes popular games, Olympic Games and various sports such as archery, swimming, and various types of ball sports such as soccer, hand, volleyball and others.

- Artistic games: It is one of the types of synthetic games such as Puzzle wither the stereoscopic (three-dimensional) or flat (two-dimensional), as well as expressive artistic activities that stem from conscience and aesthetic taste, including drawing in different colors, and the use of various materials such as clay, paper and wood.

- Language games: It represents a distinguished activity for children governed by objective rules, through which it is possible to develop the competence of language communication between children and train them in the correct use of many language tools such as letters, names, verbs and words.

- Cultural games: Through these games, the child acquires a variety of information, knowledge and experiences, includes various fictional activities such as reading and writing, as well as enjoying poetry and prose. 
- Architectural games: This type represents building and construction games with different methods and materials (Lego). ${ }^{(1)}$

From the above, it is clear to us that games have several types that differ according to the shape and the goal also have several classifications, one of those types is art puzzles that give the learner a set of various skills in addition to the enjoyment that makes learner feel free to perform his duty in educational play, so it can be defined puzzles as follows:

\subsubsection{Concept of puzzles: (Procedural definition)}

They are games that depend in their design on two basic ideas, first, "segmentation" which is a term that means dissolving parts of a thing from another, and the word "assimilation", it means joining the parts of a single thing to each other, so it becomes one, so the game is composed of More than one part and the player puts them together correctly.

The content of puzzles varies according to their scientific goal. If the goal is an artist, then the content of the game is a picture, colors, or any artistic content that achieves the goal of the artistic activity. The fields that can be learned through games can be varied according to the game design, and in the field of arts. The learner can acquire skills and knowledge in various fields of art, including: all materials such as papers, clay, metal. Textiles, wood, etc.

A set of standards must be met in art educational puzzles, which are consistent in their content with the conditions of all educational games, as follows:

\subsubsection{Characteristics and conditions that must be met in designing educational games:}

- The materials used should not be expensive, and do experiments on the game before starting to play.

- Knowing conditions of the game, also setting an educational goal to achieve it using the game.

- Designing the general shape that encourages play. ${ }^{(2)}$

- It must be balanced in its full construction of the idea and topic and clear to the children who practice it so that they know the rules of these games.

(1) Barakat Muhammad Murad: (The Child and Learning by Playing), Ministry of Endowments and Islamic Affairs, No. 524, Arab Republic of Egypt, pp. 63, 64.

(2) Ahmad Muhammad Salem: (Teaching Means and Technology), Riyadh, Al-Rasheed Library, 2004. 
- It must focus on the child's desire to play with the educational game before using it, as it is natural that there is coercion to play, that gives pleasure in its goal, and does not depend on an external reward.

- The selection of educational games must focus on the level of growth and maturity of the children who use them according to the child's level of development.

- It should include some levels of activities, and it must be clear through playing with them the ability to differentiate between behavior and its degree.

1.6.7. Stages of operations that the child performs during play: Human beings practice many mental processes while playing, which are:

- Understanding in order for the individual to play any game, he must understand its rules and limits and understand his role in the game also what (he/she) must do, to emphasize the conclusion, inference, induction and deduction.

- Analysis and synthesis in it, the individual analyzes the information intensively while playing, and then synthesizes this information to obtain a victory.

- Sentencing The lecturer urges his students to make judgments and evaluate the scientific material, all of this requires training besides practice.

- Problem Solving Human beings use all of their mental processes in solving problems.

- Flexibility and initiative: Where the educational style of games works to develop flexibility, as it provides several strategies for playing and winning. (1)

1.6.8. Benefits of educational games: The benefits of learning by playing can be illustrated in the following points:

- Emphasize the child's self as an individual who can perform valuable and useful deeds and accustom him to appreciate the value of things, learn ways to take care of them, save them from, confirm his feeling of being superior to others, satisfy the child's desire to play, bring pleasure to his heart, and make him active and effective.

- Satisfying his motivation of curiosity to enrich his information and experiences, expand the child's horizons of knowledge.

- The child learns to respect laws and rules and abides by them, which helps him to acquire good patterns of behavior.

(1) Iman Ahmed Hamdi Imam: The impact of electronic educational games and their role in developing creative thinking for students of the Faculty of Art Education at Helwan University, Emsia Magazine, 2015, pp. 97, 98. 
- Helping the child to acquire the scientific method of thinking so that he learns through its attention, focus, analysis and accuracy of observation, plus helps in the growth of memory, perception, imagination and correct pronunciation, through the processes of synthesis, analysis, classification and comparison.

- It enhances the child's belonging to the group, his acquisition of experiences from his peers, and he learns to cooperate and respect the rights of others. ${ }^{(1)}$

- Finding a state of psychological balance for the child by relieving anxiety and frustration situations and modifying aggressive, selfish and other behavior.

- The child's acquisition of some skills, training of different senses, development of fine and large muscles through the practice of some physical activities in these games.

\subsection{The second axis: stimulating the motivation for homeschooling for children of determination in light of the COVID-19 pandemic challenges}

\subsubsection{Concept of motivation:}

Motivation is the psychological physiological state within the individual that moves him to carry out a certain behavior in a specific direction to achieve a specific goal, and if this goal is not achieved, the person feels distress and tension until he achieves it, and the motives aim to reduce the state of tension in the organism and rid it of imbalance state, meaning that the organism It works to remove the exciting conditions and satisfy the motive that drives it. Several terms have been linked to the concept of the motive for their association together in the process of satisfying that motive, such as (need - motivation - emitter). ${ }^{(2)}$

- $\quad$ need It is a deficiency of a specific thing that expresses a natural desire that the organism works to achieve, thus achieving psychological balance and regularity in life, so that it is easy to harmonize and return its behavior to normal state after the appearance of disorder and a feeling of discomfort, for example the lack of food (in the body leads to certain chemical changes In blood, it indicates the individual's need for food, which gives rise to a specific incentive that directs him to search for food to satisfy his need for it and thus get rid of tension state that (he/she) was suffering from. Among the most pressing motives for a person are primary needs such as need to sleep, eat and drink.

(1)Nahida Al-Dulaimi: (Concepts at Education Kinematic), University Babylon, Iraq.

(2) Gilani Muhammad Bouhamama: Motivation and Learning, The Education Magazine, Qatar National Commission for Education, Culture and Science, 2009, Qatar, p. 158. 
- Stimulus: It is an internal stimulus of physiological origin that requires a consensual response, it usually means the internal stimuli and the organic aspects that accelerate the activity and make the organism make special responses towards a specific topic in the external environment or moving away from it, and the stimulus also appears form individual feeling of tension, distress and pain for example, a trigger associated with hunger and thirst, and an urge to feel cold or hot.

- Emitter: means the subject that the organism directs its response towards or away from it, which is what the individual perceives as something that has the ability to achieve the motive and remove the state of tension that he feels, so the emitter (an external object or an external stimulus) corresponds to the stimulus associated with it. ${ }^{(1)}$

Through these concepts, the relationship between motivation, need, motivation and motivation can be clarified as follows:
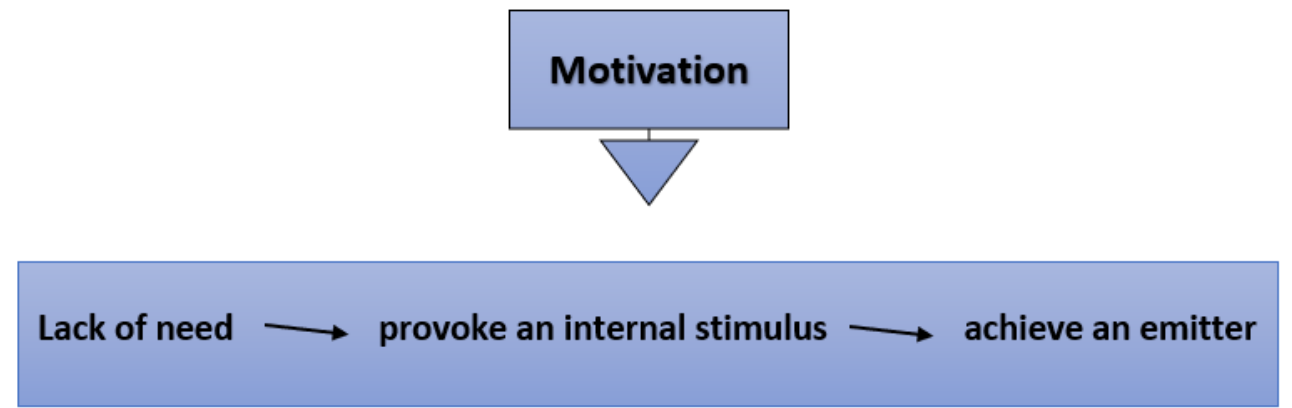

By recognizing that interconnected relationship between need, stimulus and emitter, we can develop educational programs to stimulate the motivation of the learner, as well as by identifying the role and characteristics of motives, thus enabling the teacher to develop educational programs that achieve the goals of the educational process and can be summarized in the following points:

- Directing the behavior: Motives are characterized by directing the behavior towards a specific goal.

- Change and diversification of behavior: that is, the motives begin to change the behavior of the individual then begin to diversify his activity in order to achieve the satisfaction of the motive.

(1) Gilani Muhammad Bouhamama: The aforementioned reference, p. 159. 
- Purpose: Each motivation has a specific goal that works to end the state of tension arising from its lack of satisfaction.

- Activity: The motivation moves the individual activity to satisfy the motivation, so the activity increases as the strength of the motive increases to reach the response which satisfies it.

- Continuity: organism continues until it achieves the required satisfaction and ends the stress state.

- Improvement: A person tends to improve during his attempts to satisfy the motivation, which causes him to repeat the behavior that achieves its satisfaction.

- Total adaptation: The activity of the organism to achieve the purpose requires it to move all parts of the body, meaning that the satisfaction of the motive requires the organism to adapt generally. The greater the significance and strength of the motive, the greater needs of total adaptation.

- Stopping the behavior: the behavior of the organism stops if the purpose for which it was aimed is achieved, in other words, when the motive is satisfied. ${ }^{(1)}$

\section{Table 1 - Motives can be divided into two basic types as following:}

\begin{tabular}{|c|c|c|}
\hline Concept & $\begin{array}{l}\text { They are organic and } \\
\text { biological needs that a } \\
\text { person needs to satisfy in } \\
\text { order to survive. }\end{array}$ & $\begin{array}{l}\text { They are psychosocial needs that are acquired through } \\
\text { learning through contact with life and society. }\end{array}$ \\
\hline Presence & $\begin{array}{l}\text { They are found in } \\
\text { humans and most living } \\
\text { things, such as animals } \\
\text { and plants, but in } \\
\text { different ways. }\end{array}$ & It is only present in humans. \\
\hline Examples & $\begin{array}{l}\text { (Hunger, thirst, } \\
\text { motherhood, sex, } \\
\text { excretion, sleep, rest, } \\
\text { etc.) }\end{array}$ & $\begin{array}{l}\text { (Community love, control, possession, curiosity, } \\
\text { religion, social standing, power, fame, self-affirmation, } \\
\text { learning, belonging to a group, etc.) }\end{array}$ \\
\hline Diversity & Varied but limited & Infinite variety \\
\hline Source & biology is not acquired & $\begin{array}{l}\text { A social acquired and subject to development and } \\
\text { learning through internal excitement, it is a force } \\
\text { stemming from the individual that drives him to learn } \\
\text { and acquire new skills or through external excitement } \\
\text { such as praise, encouragement, gift giving, and also the } \\
\text { pride of parents or teacher. }\end{array}$ \\
\hline
\end{tabular}

(1) Gilani Muhammad Bouhamama: A previously mentioned reference, pp. 159, 160. 
From the above, it is possible to distinguish between motives and their types, as well as know that external motives are what we all subject to once we reach the age of perception, which is what we practice in our normal life every day, so we gain life skills, coexistence and learning. Therefore, a strategy can be developed through identifying some of the different motivation theories, that leading to put the foundations, which the teacher or parents can use to develop their children of determination skills to saves time and effort that They have to homeschooling compared to unstructured learning, and these theories varied on the basis of the classification of need also the extent to which a person needs it, so we will present some theories that are concerned with the cognitive aspect and the educational field, the most prominent of which are:

\section{- Maslow's theory of needs:}

Maslow sees, "1998': A specific method for categorizing human needs and motives that grow in a hierarchical manner to achieve needs of high levels, whereby a person starts from the basic needs which he is born with and escalates into psychological needs whose importance does not appear until after basic biological needs are satisfied. Maslow has been identified. In its hierarchical classification of needs seven levels, physiological or biological needs come at the base of the pyramid, and the need for security comes second from the base, there for a person's need to feel secure, and then comes the need for love and belonging, because of the person's need to be loved in the midst of those around him, after that comes the need for a sense of self-esteem because of his need to achieve his personal value and the importance of the role he represents in society, and near the top of the pyramid comes the need for knowledge and understanding and means the desire stemming from the human being to explore and obtain more information. These needs are clearer for some individuals than they are for others, and the stronger the knowledge and understanding needs of the individual, the more they are accompanied by a desire for systematic practice based on analysis, organization, linking and research in the relationships between things.

\section{The indications that refer to cognitive needs are summarized in the following points:}

- The individual's ability to sense the existence of problems that need research and investigation

- using the exploratory method in acquiring information, principles, facts, or finding solutions to problems.

- Curiosity that drives human to discover the environment which he lives in, also knowledge about himself and his environment. 
At the top of the pyramid of motives for Maslow comes the need for beauty, and these needs appear in the tendency of aesthetic values, which are reflected in their preference for arrangement, consistency, perfection and beauty, in all their activities.

From the above, it can be said that the "Maslow" theory of motivations and needs are the most comprehensive theories that deal with human needs and shed light on the cognitive needs that in turn can be used in several educational applications, and it is one of the theories which affect on educational construction, and in order to upgrade the effectiveness of the curriculum for learners, the teacher must take into consideration the needs of students and the hierarchical arrangement, where the priority is to help them achieve basic needs first before reaching the higher levels of the needs hierarchy, so if the student does not fulfill his primary needs such as food and drink, it is difficult to obtain his attention and focus on learning and knowledge. ${ }^{1)}$

\section{- The theory of excitement:}

Excitement is a fundamental concept in many learning theories, and we mean the capacity and energy that an individual has to carry out a specific activity. Perhaps the most famous scientific study on the topic of excitement is that of Yerkes and Dodson (Yerkes and Dodson) where they expressed the topic of excitement in an inverted U-shaped diagram that represents the functional relationship between excitement and motivation. A certain level of excitement can lead to change (learning), while extreme degrees of motivation (strength or weakness) may lead to A kind of deterioration and disruption in performance, because an increase in motivation may cause physical weakness or the emergence of some emotional states, or it may lead to laziness and dullness in the case of a lack of motivation, therefore a person needs a reasonable or moderate level of excitement to push him to learn. ${ }^{(2)}$

\section{- Achievement motivation theory:}

this theory attributed to "Atkinson" and he defines it as a relative predisposition in personality that determines the extent to which the individual strives and perseveres in order to achieve success that results in a kind of gratification, "Atkinson" believes that the human being has an enormous amount of energy and a set of basic needs or motives that he likens to valves or outlets It works to direct and regulate the flow of this potential energy in the individual, "Atkinson" assumes Most people across cultures differ greatly among themselves regarding the relative

(1) Maslow, A., \& Lowery, R. (Ed.). (1998). Toward a psychology of being (3rd ed.). New York: Wiley \& Sons.

(2) Maslow, A., \& Lowery, R. (Ed.). (1998). Toward a psychology of being (3rd ed.). New York: Wiley \& Sons. 
strength of these motivation, also Atkinson assumes that a strong motivation resembles a valve or an energy outlet that opens easily and then follows a greater flow of energy, while a weak motivation resembles a narrow valve that allows for an influx. Determined, and that the achievement behavior is determined by two needs that are characterized by competition, namely the motive for success and the drive to avoid failure, the motivation for success means that the individual performs a task or action with great activity and enthusiasm and that is in his desire to obtain a sense of success, and to achieve this success the individual must set moderate goals The difficulty in avoiding failure makes the individual avoid to perform a certain task for fear of failure that he may face when performing it, unlike the motivation for success where the individual sets medium goals, the individual motivated to avoid failure sets very easy goals to reduce the possibility of failure, Atkinson has found that all People have an incentive to avoid failure as much as they have an incentive For achievement, success and achievement. ${ }^{(1)}$

In light of these theories, a set of suggestions can be developed to achieve the highest desired percentage of the educational goal, which is to motivate students of determination to learn through play and gain artistic experiences for their homeschooling during COVID-19 pandemic:

- Encouraging learners to learn and know through activities, play, exploration, and finding facts.

- Distributing students to similar cognitive levels so that they do not become frustrated and abandoned when they drive to learn and explore.

- Give learners ample time to discover their areas of interest and get to know them with enthusiasm and curiosity.

- Providing telekinetic suitable with their cognitive levels.

- Seeking with the learners to expand their motives valves of learning and knowledge by entrenching their concepts of achievement.

- Exciting learners and pushing them to approach updated educational topics.

- Encouraging learners to participate in educational programs that are challenging for their cognitive levels, abilities and skills.

(1) Atkinson.J. (1965). The mainspring of achievement orietntal activity. In JD Grunballs (Ed.) Learning and the educational processes. Skokie.IL. Rond McNally. 
- Rewarding and motivating learners with moderate stimuli at each level of cognitive achievement.

- Avoiding punishment in the case of failure to achieve goals and descending to a level of knowledge or skills that is less compatible with the level of the learner.

\subsubsection{Standards and considerations that must be observed in guiding learners of}

\section{determination:}

- Developing learners' information of determination by training the different senses, such as using the sense of sight and touch together.

- Verbal instructions should be clear, simple and repeatable.

- Parents encourage their children of determination to express themselves, throw trying to verbally comment on pictures, games and situations.

- the information entry for the learners should be directed so that it starts from the physical and the perceptual to the abstract, from the familiar to the unfamiliar as well as from easy to difficult to achieve a higher success rate.

- Linking topics with each other so that information becomes homogeneous, so that it becomes easier to understand and strengthens the connection of information with their imaginations.

- Presenting the scientific material in a fragmented manner and making sure that the learner has passed and understood this part before completing the other parts.

- parents should Encourage and motivate their children of determination constantly, whether physically with gifts, or verbally through praise.

- Use the teaching aids that are appropriate for each category of people of determination, for example, it is not possible to rely on games with sound effects for deaf children, so parents must choose games that are appropriate for their children's category.

- Taking into account the child's psychological, physical condition also their preparations for playing and learning.

In addition to those considerations that we have listed, parents must also focus on the behavioral characteristics and needs required by each class of learners based on knowledge of their classification and the resulting deficiency then trying to correct it, and the following is a presentation for some groups of people of determination who are able to learn and their characteristics: 
Classification and properties Some categories of learners with disabilities that parents must

take into account during homeschooling them:

Table 2

\begin{tabular}{|c|c|c|c|}
\hline The point of & \multicolumn{3}{|c|}{ People with intellectual disability } \\
\hline $\begin{array}{c}\text { learners } \\
\text { Categories of } \\
\text { people of } \\
\text { determination } \\
\end{array}$ & Autism & $\begin{array}{l}\text { Psychosis or } \\
\text { schizophrenia }\end{array}$ & $\begin{array}{l}\text { Mental retardation and } \\
\text { Down syndrome }\end{array}$ \\
\hline $\begin{array}{c}\text { Types of } \\
\text { educational } \\
\text { aids available } \\
\text { to them }\end{array}$ & $\begin{array}{c}\text { Aids based on the senses } \\
\text { that do not provoke } \\
\text { anger, such as (sharp and } \\
\text { loud sounds, } \\
\text { phosphorescent colors } \\
\text { that are painful to the } \\
\text { eyes) }\end{array}$ & $\begin{array}{l}\text { Aids that working } \\
\text { with all senses, take } \\
\text { into account the level } \\
\text { of mental intelligence, } \\
\text { and help attract } \\
\text { attention and focus }\end{array}$ & $\begin{array}{l}\text { Aids that working with } \\
\text { all senses and take into } \\
\text { account the level of } \\
\text { mental intelligence }\end{array}$ \\
\hline \multirow[t]{2}{*}{$\begin{array}{l}\text { Psychological } \\
\text { support } \\
\text { requirements }\end{array}$} & $\begin{array}{l}\text { Be patient in dealing with } \\
\text { them, understand their } \\
\text { requirements, and create } \\
\text { an appropriate } \\
\text { atmosphere for learning, } \\
\text { such as listening to quiet } \\
\text { music and seeking } \\
\text { medical supervision }\end{array}$ & $\begin{array}{l}\text { Be patient in dealing } \\
\text { with them, understand } \\
\text { his special situation } \\
\text { and requirements, and } \\
\text { create a suitable } \\
\text { atmosphere for } \\
\text { learning, under the } \\
\text { supervision of a } \\
\text { specialist }\end{array}$ & $\begin{array}{l}\text { Be patient in dealing } \\
\text { with them, know the } \\
\text { level of his mental } \\
\text { intelligence, } \\
\text { understand his special } \\
\text { condition and } \\
\text { requirements, and } \\
\text { create the right } \\
\text { atmosphere for } \\
\text { learning. }\end{array}$ \\
\hline & \multicolumn{3}{|c|}{$\begin{array}{l}\text { Moving away from drawing their attention to their shortcomings and } \\
\text { slowing down, waiting for responding and encourage them. }\end{array}$} \\
\hline $\begin{array}{c}\text { Distinguishing } \\
\text { characteristics } \\
\text { of them }\end{array}$ & $\begin{array}{l}\text { Some autistic patients } \\
\text { have very strong abilities } \\
\text { and talents that reach for } \\
\text { invention and they have } \\
\text { the ability to focus, work } \\
\text { alone and accomplish } \\
\text { complex difficult, also } \\
\text { they have the ability to } \\
\text { memorize }\end{array}$ & They do not have & $\begin{array}{l}\text { They are distinguished } \\
\text { by kindness, especially } \\
\text { down syndrome, and } \\
\text { they are distinguished } \\
\text { by the love of people } \\
\text { and community } \\
\text { participation, and they } \\
\text { have the ability to } \\
\text { imitate, simulate, } \\
\text { perform simple } \\
\text { household tasks and } \\
\text { learn in accordance } \\
\text { with their mental } \\
\text { levels. }\end{array}$ \\
\hline
\end{tabular}




\begin{tabular}{|c|c|c|c|}
\hline Prohibitions & $\begin{array}{c}\text { Staying away from } \\
\text { surprises, taking into } \\
\text { account the problems he } \\
\text { suffers from such as loud } \\
\text { sound, light, contact with } \\
\text { strangers, change and } \\
\text { constant renewal, or } \\
\text { taking his belongings that } \\
\text { he prefers }\end{array}$ & $\begin{array}{l}\text { Not provoking him by } \\
\text { blaming him in case } \\
\text { of error and removing } \\
\text { stimuli that may help } \\
\text { arouse delusion, such } \\
\text { as the use of abstract } \\
\text { and imaginary words, } \\
\text { thus stimulating his } \\
\text { mind to plunge into } \\
\text { the world of } \\
\text { imagination. }\end{array}$ & $\begin{array}{l}\text { Avoid intense } \\
\text { interactions with them, } \\
\text { as they are quick to } \\
\text { anger and sensitive to } \\
\text { feelings, and not to } \\
\text { give them tasks higher } \\
\text { than their capabilities } \\
\text { so that they do not } \\
\text { become frustrated and } \\
\text { fail, which leads to a } \\
\text { delay in their level. }\end{array}$ \\
\hline $\begin{array}{l}\text { Associated } \\
\text { problems }\end{array}$ & $\begin{array}{l}\text { Inability to communicate } \\
\text { with others visually and } \\
\text { emotionally and does not } \\
\text { like change and renewal, } \\
\text { so he prefers routine and } \\
\text { repetition in words and } \\
\text { physical movements, } \\
\text { inability to express } \\
\text { linguistic or emotional } \\
\text { expression and is very } \\
\text { sensitive to light, sound } \\
\text { and touch and may get } \\
\text { upset quickly and have an } \\
\text { exaggeration in reaction }\end{array}$ & $\begin{array}{l}\text { Inability to focus, } \\
\text { cannot feeling } \\
\text { emotions and feelings, } \\
\text { delusions in things } \\
\text { that have no basis in } \\
\text { reality, whether } \\
\text { visually or auditory, } \\
\text { etc., to feel that he is } \\
\text { right, as he has a lack } \\
\text { of motivation, and the } \\
\text { patient is not aware of } \\
\text { his problem, which } \\
\text { makes it difficult to } \\
\text { deal with him. }\end{array}$ & $\begin{array}{l}\text { Understanding their } \\
\text { problems with mental } \\
\text { retardation, mental, } \\
\text { health and physical } \\
\text { problems for patients } \\
\text { with Down syndrome } \\
\text { due to chromosome } \\
\text { defects that effect on } \\
\text { heart, blood pressure } \\
\text { and body functions in } \\
\text { general }\end{array}$ \\
\hline
\end{tabular}

$\underline{\text { Table } 3}$

\begin{tabular}{|c|c|c|c|}
\hline $\begin{array}{l}\text { The point of } \\
\text { comnarison }\end{array}$ & \multicolumn{3}{|c|}{ People with physical and motor disabilities } \\
\hline $\begin{array}{c}\text { learners } \\
\text { Categories of } \\
\text { people of } \\
\text { determination }\end{array}$ & $\begin{array}{l}\text { Loss one of a hand } \\
\text { limb }\end{array}$ & $\begin{array}{l}\text { Loss one of the foot } \\
\text { limb }\end{array}$ & Stunting \\
\hline $\begin{array}{c}\text { Types of } \\
\text { educational } \\
\text { aids available } \\
\text { to them }\end{array}$ & $\begin{array}{l}\text { Aids based on simple } \\
\text { control of the limbs of } \\
\text { the hand, foot, and the } \\
\text { rest of the five senses }\end{array}$ & $\begin{array}{l}\text { Aids depend on } \\
\text { controlling the limbs of } \\
\text { the hand, foot, and the } \\
\text { rest of the five senses }\end{array}$ & $\begin{array}{l}\text { Aids depend on simple } \\
\text { control of the limbs of } \\
\text { the hand and foot and } \\
\text { the rest of the five } \\
\text { senses, and take into } \\
\text { account } \\
\text { Fit lengths }\end{array}$ \\
\hline
\end{tabular}




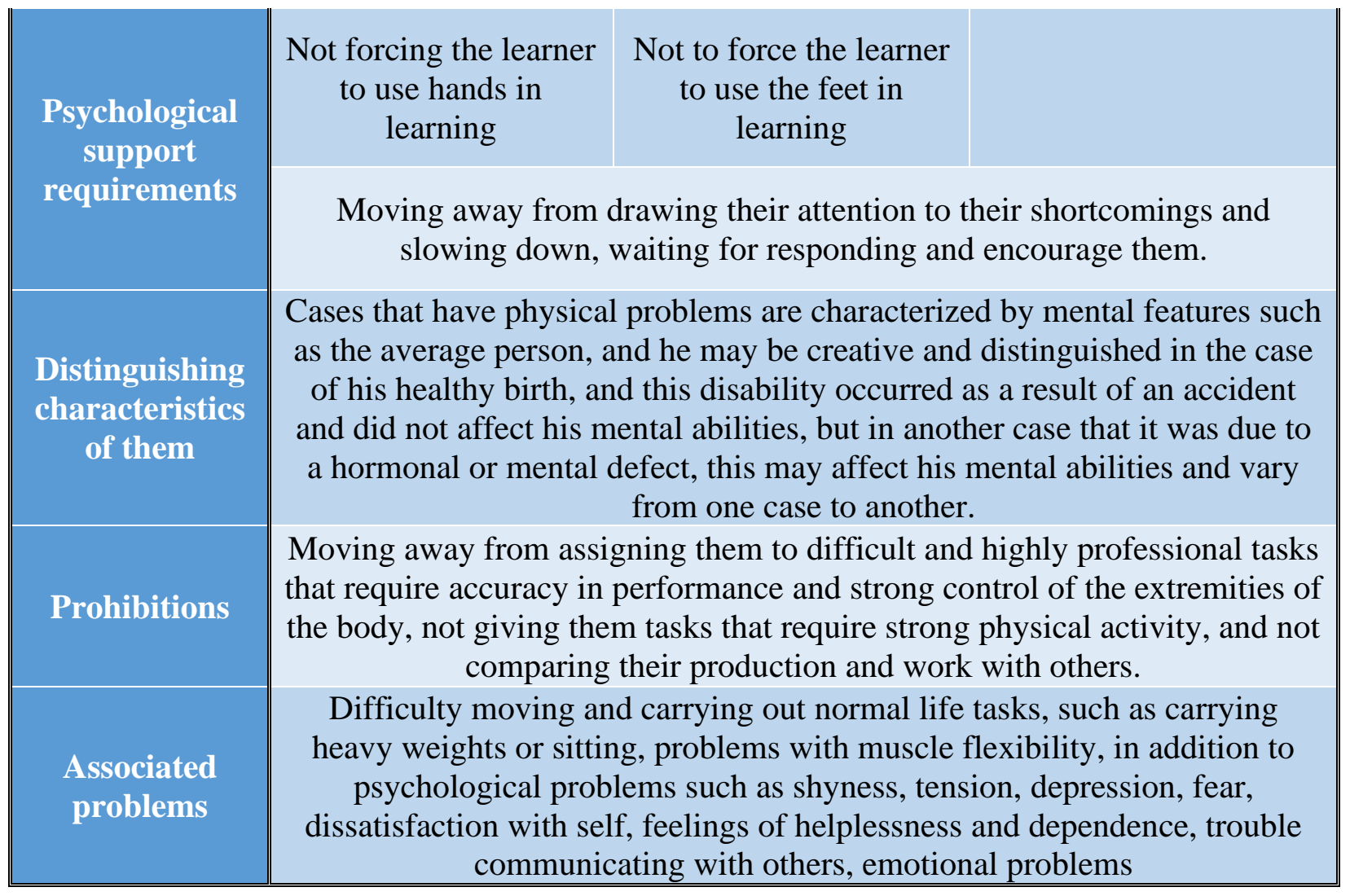

\section{Table 4}

\begin{tabular}{|c|c|c|c|}
\hline The point of & \multicolumn{3}{|c|}{ People with a sensory disability } \\
\hline $\begin{array}{l}\text { Categories of } \\
\text { people of } \\
\text { determination }\end{array}$ & $\begin{array}{l}\text { Blind and visually } \\
\text { impaired people }\end{array}$ & Deaf and dumb & $\begin{array}{l}\text { Hearing impaired } \\
\text { and speech impaired }\end{array}$ \\
\hline $\begin{array}{c}\text { Types of } \\
\text { educational } \\
\text { aids available to } \\
\text { them }\end{array}$ & $\begin{array}{l}\text { Tactile, auditory and } \\
\text { taste aids }\end{array}$ & $\begin{array}{l}\text { Visual, tactile and } \\
\text { gastronomic aids }\end{array}$ & $\begin{array}{l}\text { Visual, tactile, taste } \\
\text { and aural aids }\end{array}$ \\
\hline \multirow{2}{*}{$\begin{array}{l}\text { Psychological } \\
\text { support } \\
\text { requirements }\end{array}$} & $\begin{array}{l}\text { Not highlighting } \\
\text { weaknesses like staying } \\
\text { away from provocative } \\
\text { words like (look, faster) }\end{array}$ & $\begin{array}{l}\text { Using sign language and } \\
\text { not speaking in front of } \\
\text { them with another } \\
\text { person to avoid negative } \\
\text { impact and distraction }\end{array}$ & $\begin{array}{l}\text { Speak loudly and } \\
\text { clarify lip } \\
\text { movements to } \\
\text { support and clarify } \\
\text { the voice }\end{array}$ \\
\hline & $\begin{array}{l}\text { Moving away from } \\
\text { slowing down }\end{array}$ & $\begin{array}{l}\text { ing their attention to th } \\
\text { ing for responding and }\end{array}$ & $\begin{array}{l}\text { shortcomings and } \\
\text { courage them. }\end{array}$ \\
\hline
\end{tabular}




\begin{tabular}{|c|c|c|c|}
\hline $\begin{array}{l}\text { Distinguishing } \\
\text { characteristics } \\
\text { of them }\end{array}$ & $\begin{array}{c}\text { They have a high ability } \\
\text { to pay attention to } \\
\text { sounds and a strong } \\
\text { auditory memory. }\end{array}$ & $\begin{array}{c}\text { They have quick wit, } \\
\text { sharp visual intelligence, } \\
\text { and strong visual } \\
\text { memory. }\end{array}$ & $\begin{array}{l}\text { They have the same } \\
\text { characteristics as a } \\
\text { normal, physically } \\
\text { healthy person. }\end{array}$ \\
\hline Prohibitions & $\begin{array}{l}\text { Moving away from } \\
\text { sharp tools and using } \\
\text { abstract concepts and } \\
\text { not leaving him alone } \\
\text { due to the difficulty in } \\
\text { assessing situations and } \\
\text { the difficulty of his } \\
\text { communication with } \\
\text { society }\end{array}$ & $\begin{array}{l}\text { Avoid expressions of } \\
\text { angry and confusing } \\
\text { them }\end{array}$ & $\begin{array}{l}\text { Stay away from the } \\
\text { use of a faint voice }\end{array}$ \\
\hline $\begin{array}{l}\text { Associated } \\
\text { problems }\end{array}$ & $\begin{array}{l}\text { Difficulty moving solo, } \\
\text { emotional disorder }\end{array}$ & $\begin{array}{c}\text { Rapid to anger and } \\
\text { tension, and this appears } \\
\text { on the features of their } \\
\text { faces }\end{array}$ & $\begin{array}{c}\text { Rapid to anger and } \\
\text { tension, but less } \\
\text { intense than deaf and } \\
\text { dumb }\end{array}$ \\
\hline
\end{tabular}

1.7.3. Gaming features suitable with all categories of people of determination:

- Clarity and definition of the goal, instructions and levels compatible with the learner.

- Variety of stimuli appropriate for the category of the learner.

- Allow free time to respond (unlimited time).

- It is characterized by ease of performance, also simple progression from most difficult stages to instill self-confidence.

- It is characterized by embodiment and clarity, so it is tangible to the learner, and attractive, friendly colors that bring joy, psychological comfort and stimulate him to learn.

- Play with it can be repeated upon fail, enabling learning to learn through trial and error.

- It allows the possibility of playing with it by one or more individuals, and it helps to develop interactive and integrative skills.

- Helps to develop motor skills, which leads to the development of mental motor synergy.

- It helps to develop the skills of thinking, observation and perception, which leads to the strengthening of spontaneity and interaction.

\section{Material and Method: an explanation and analysis of the applied aspect:}

The researcher followed the experimental approach in the application side of the research through practical group of second year students - Art Education Department - Faculty of Specific Education - Alexandria University, with the aim of designing and implementing art educational puzzles to motivate homeschooling for people of determination in light of the COVID-19 pandemic, Taking into account the characteristics and conditions that must be in designing educational games as previously explained, and the motivational suggestions that are based on the 
theories of motivation for each of (Maslow, Yerkes and Dodson, Atkinson and characteristics of games that are appropriate for some groups of learners with disabilities.

\subsection{First: Steps to apply practical experience:}

Duration of the experiment: The experiment took two weeks for the theoretical analysis of the art educational puzzles, two weeks for its design, and four weeks for its implementation, so all in all a period of 8 continuous weeks, beside that the duration of one session was four hours, and it was as follows:

First: Narration, analysis and discussion of the theoretical aspect of the concept of educational games and their types, especially art educational puzzles, analyzing and discussing the possibility of motivating some groups of learners with determination, what are the appropriate motivation methods for these groups and their characteristics and psychological needs for them For homeschooling in light of the COVID-19 pandemic, second: designing art educational puzzles according to specific target groups of that game, an educational goal in one of the fields of art education and also in accordance with research data, the material were wood, strings and safe colors so as not Harmful to learners, third: start implementing the game and determining the size that suits the needs of the learners, then start cutting the materials used in each game, installing them, then coloring and finishing them to be ready for use. Fourth: Creating a step explaining booklet of the game to make it easier for parents to understand the way of playing for explaining it to the educated children of people of determination during homeschooling periods in light of COVID-19 pandemic, with the aim of acquiring various skills, art education and psychological recreation. Fifth: Applying a questionnaire to measure the suitability of art educational puzzles implemented to achieve goals the research is governed by a group of lecturers of Art Education Department - Faculty of Specific Education - Alexandria University.

\subsection{Second: Results of applying practical experience:}

- Game No. 1: The objectives of the game: To get acquainted with some shades of colors such as blue, red, yellow and green, and to strengthen the kinetic synergy of the commands of the mind by trying to link the shape with the corresponding space of the same shape, and to identify the different shapes.

Target group: All groups except people of determination who lost both limbs of their hands or the blind. 
The way of playing: the learner tries to place the shape in the corresponding space in the order from dark to light for the same color, then move to the other color and finish all the colors in this way as shown in the pictures:
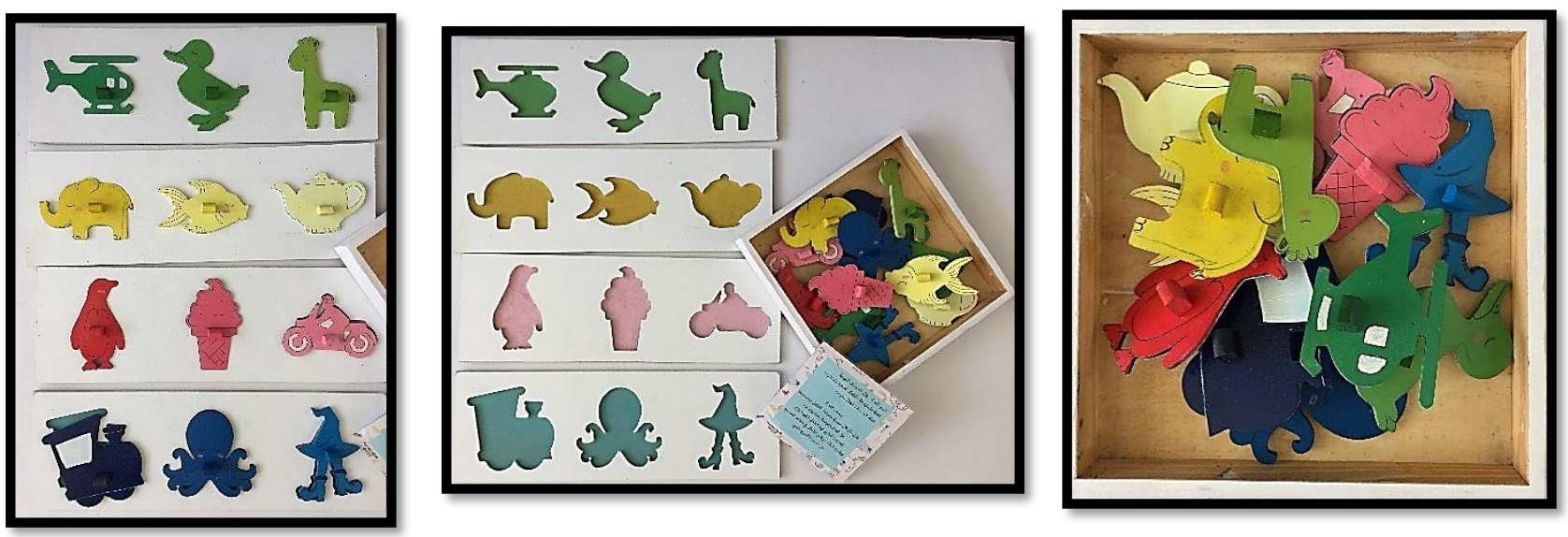

- Game No. (2): The objective of the game: Learn about the color circle that combines the primary and secondary colors, and strengthen the kinetic synergy of the mind commands by placing the pieces and small balls in places identical to their color.

Target group: All groups except people of determination who lost both limbs of their hands or the blind.

The way of playing: The learner should try to place the parts of the color circle disassembled in a fixed order from right to left, as in the following pictures:
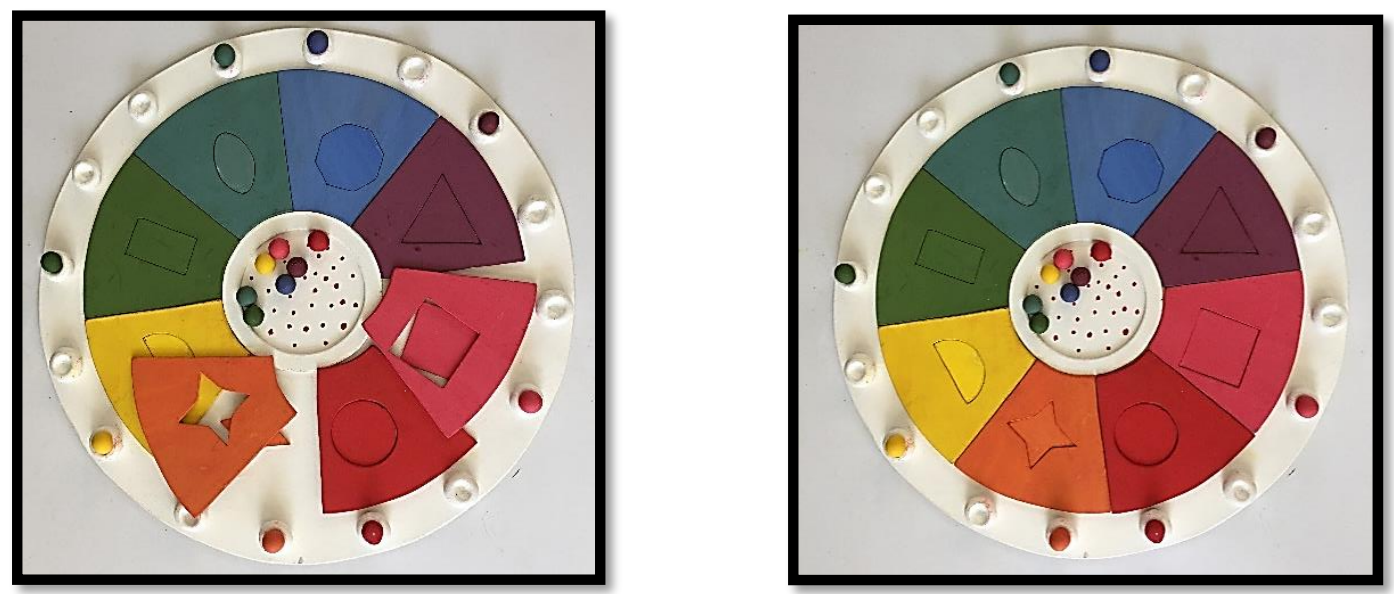

- Game No. (3): The objective of the game: Recognizing simple geometric shapes, enhancing the ability of memory to remember and memorizing, and strengthening the motor synergy of 
the mind commands by trying to control the hand to place the cubes in the appropriate places for them.

Target group: All groups except people of determination who lost both limbs of their hands or the blind.

The way of playing: The learner tries to create images of geometric shapes by placing small cubes inside each square, using the drawing of the shape from memory, as in the following pictures:
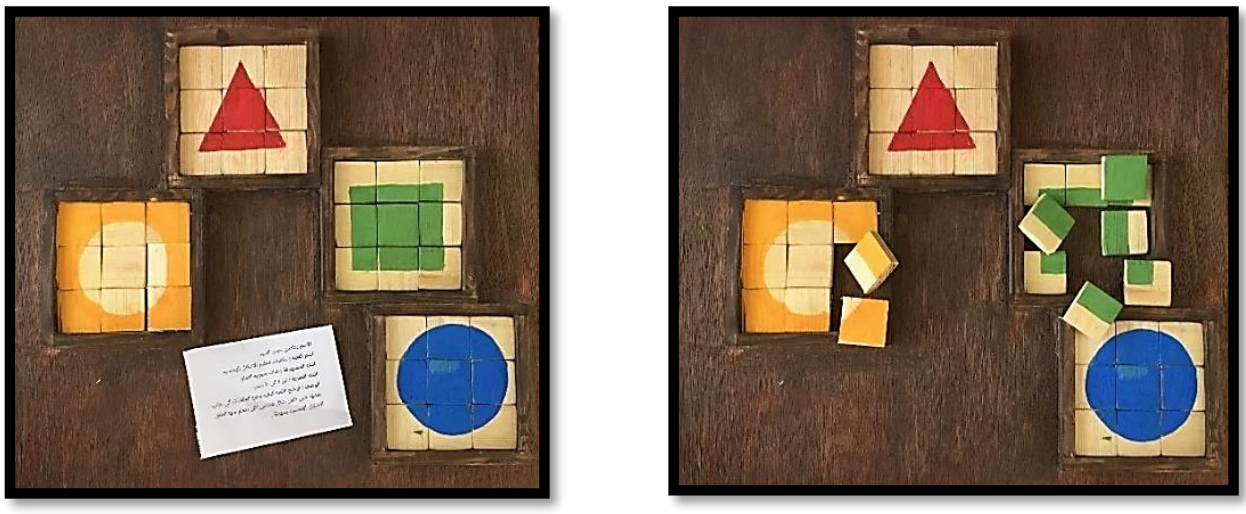

- Game No. (4): The objective of the game: Identifying geometric shapes and their sizes, identifying basic colors except for the blind category, developing the learner's ability to estimate sizes and matching them with the appropriate space, and strengthening the kinetic synergy of the hand with mind commands.

Target group: All groups, except people of determination who lost both limbs of their hands.

The way of playing: the learner tries to place the different geometric pieces, starting from the largest to the smallest, in their correct places, without placing the piece in a space with different size, and the possibility of changing the shapes board and choosing another geometric shape as shown in the pictures.
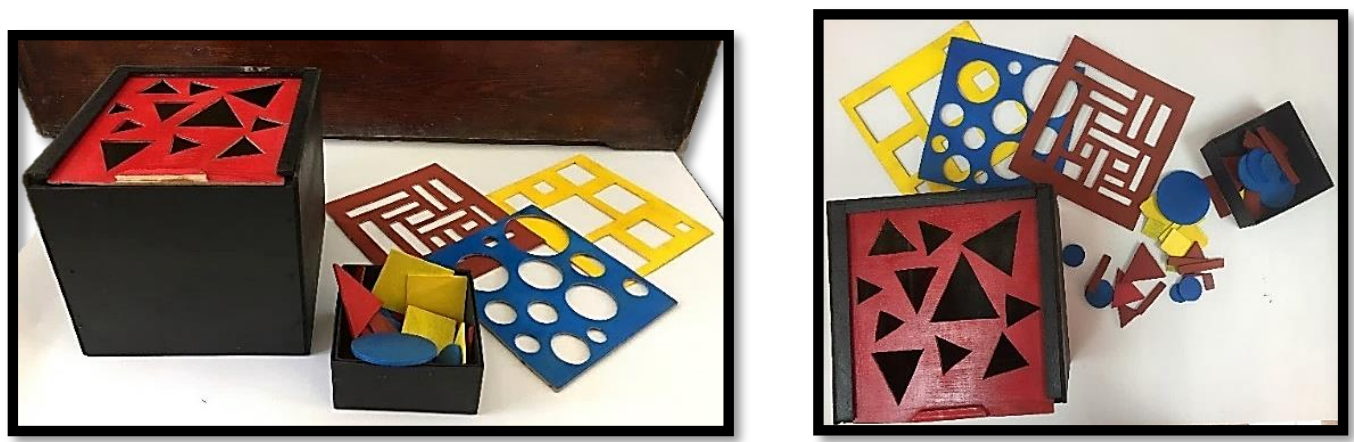
- Game No. (5): The objective of the game: Recognizing the concept of decorative arts through that decorative unit and the concept of coordinating and distributing colors, developing the learner's ability to control the muscles of the hand, stimulating memory, and strengthening the motor synergy of the hand with the mind commands.

Target group: Suitable for groups with high intelligence, such as the gifted, deaf, dumb, blind and some autistic children.

The way of playing: The learner should try to use the space, then match and place the various decorative pieces in their places to form a beautiful decorative unit as shown in the pictures:
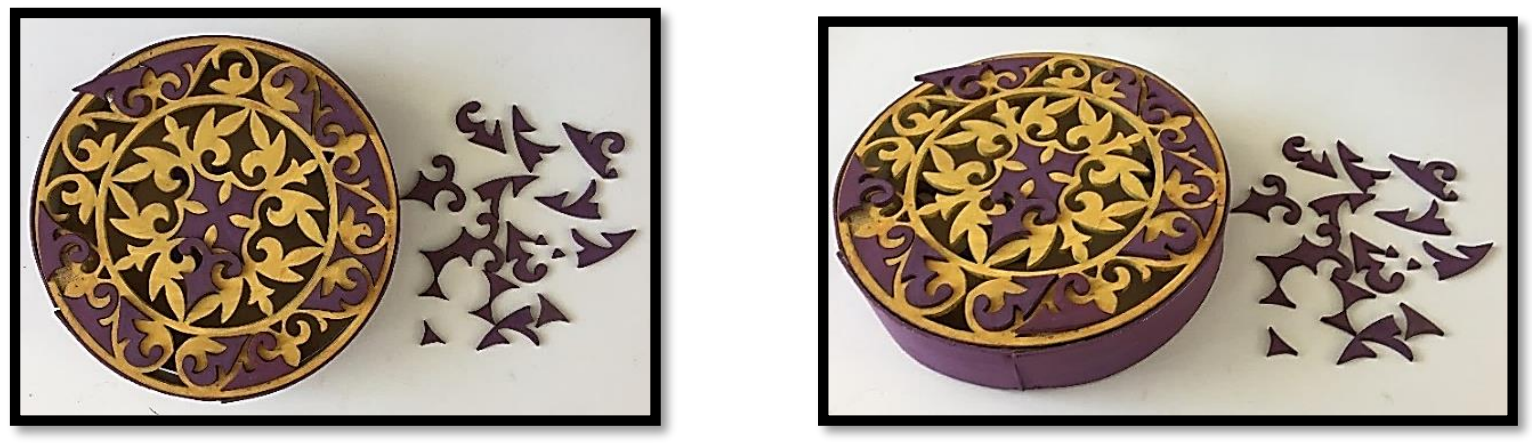

- Game No. (6): The objective of the game: Developing the learner's creativity and creating different images using basic geometric shapes, stimulating memory, enhancing the ability to imitate and matching, inculcating some aesthetic concepts of artistic design, and strengthening the motor synergy of the hand with the mind orders.

Target group: Suitable for all groups except the blind and mental retardation groups.

The way of playing: the learner to try to focus on the picture drawn in the small square in front of him and try to complete it using simple geometric pieces and put them in their places to create an aesthetic scene, as shown in the pictures:
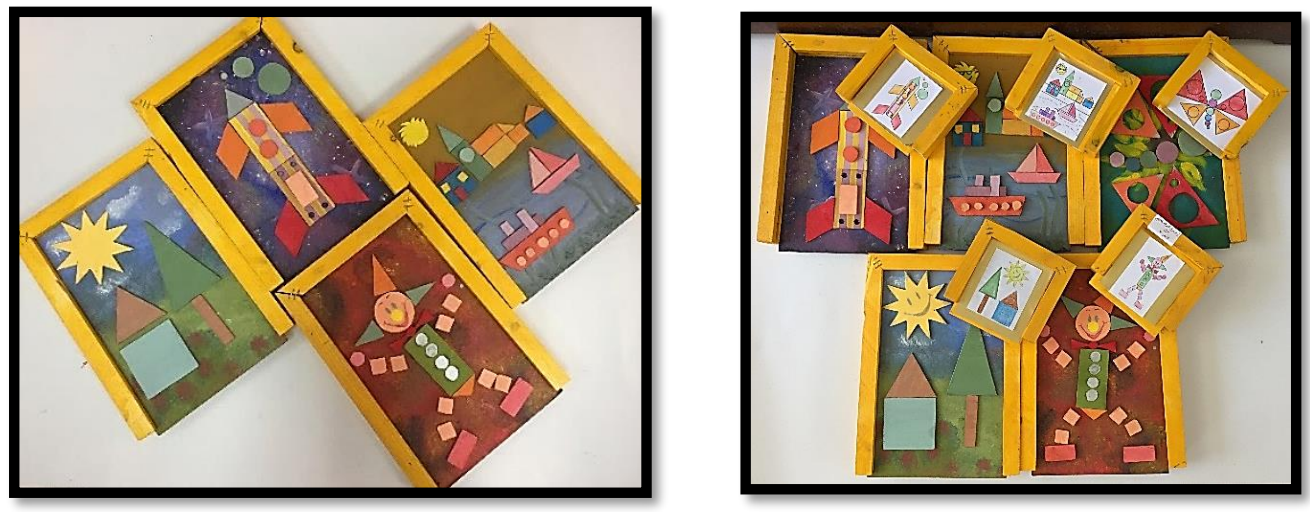
- Game No. (7): The objective of the game: Recognizing simple geometric shapes, developing the learner's creativity and creating different images using simple basic geometric shapes, stimulating memory and enhancing the ability to imitate and simulating images, strengthening the control of the delicate hand muscles.

Target group: Suitable for groups with high intelligence, such as the gifted and some autistic children, except the blind.

The way of playing: the learner tries to focus on imitating the innovative image of geometric shapes in the attached cards and trying to imitate them using small geometric pieces trying to create new shapes, as shown in the pictures:
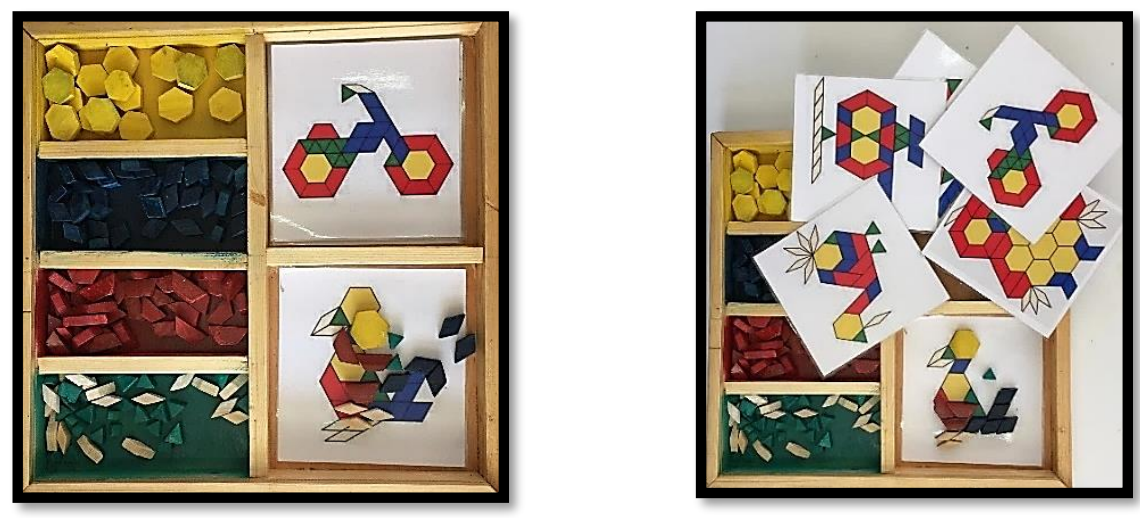

- Game No. (8): The objective of the game: Recognizing the shapes and colors of fruits, activating the memory and enhancing the ability of simulation and matching, broadcasting the concept of order and arrangement, strengthening the motor synergy of the mind commands.

Target group: Suitable for all categories of people of determination, except the blind.

The way of playing: The learner should try to simulate the shape of the fruit by arranging the wooden stick on which the parts of the fruit are drawn in a correct order, as shown in the pictures:
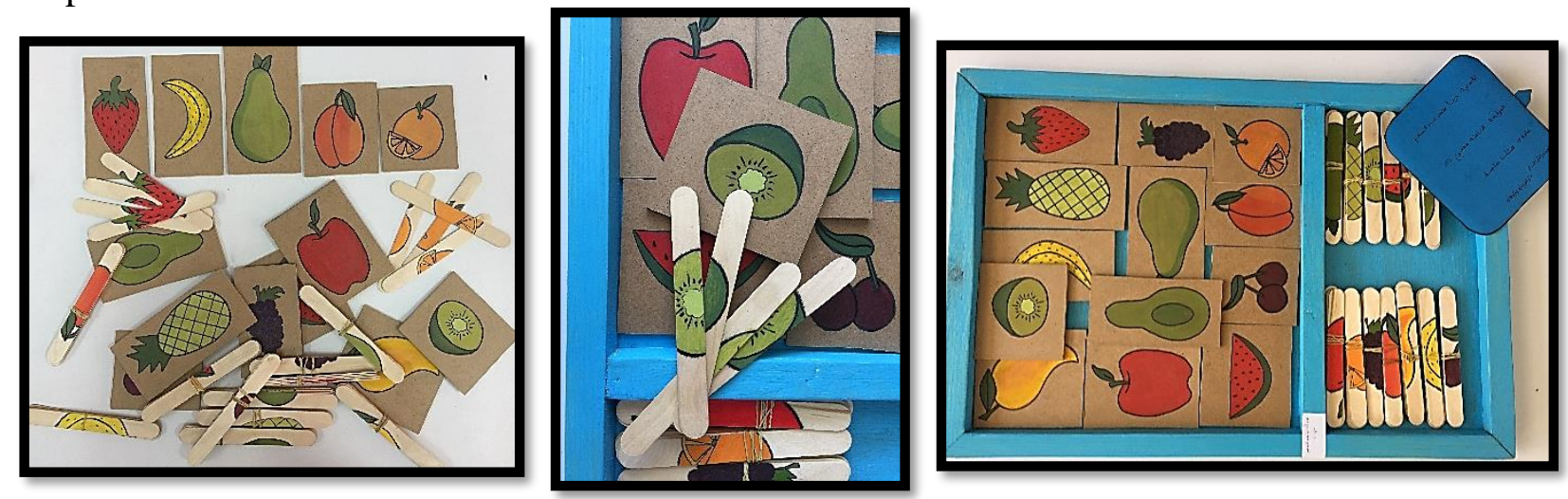
- Game No. 9: The Objective of the Game: Identify one of the art printing methods, which is fingerprint printing, venting negative psychological feelings, transmitting the concept of order and arrangement through playing in a specific and designated place, strengthening the kinetic synergy of the hand with the mind commands.

Target group: Suitable for all categories of people of determination, except the blind.

The way of playing: the learner tries to put the watercolors from the color tube on the face of the rubber fingerprint, then spread them out using the sponge roller and print them on the cloth pieces attached to the game, and these shapes can also be printed on the learner's clothes using the fabrics pigments with parents help, as shown in the pictures:
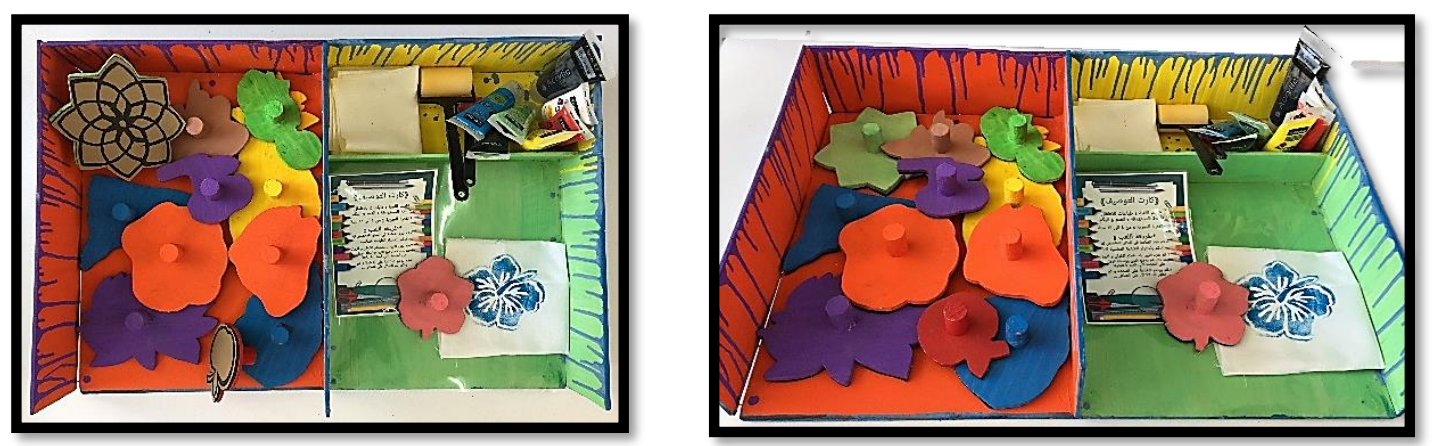

- Game No. (10): The objective of the game: Recognizing the simplest manual weaving methods, releasing negative psychological emotions, strengthening the learner's ability to focus, transmitting the concept of order and arrangement by returning the contents of the game in the box, strengthening the motor synergy of the hand with the mind commands.

Target group: Suitable for all groups of people of determination.

The way of playing: The learner tries to use the string and the plastic needle attached to the game to poke it into the opening small circles of each animal shapes piece to give it a textile texture like a fabric and complete the shape, as shown in the pictures:
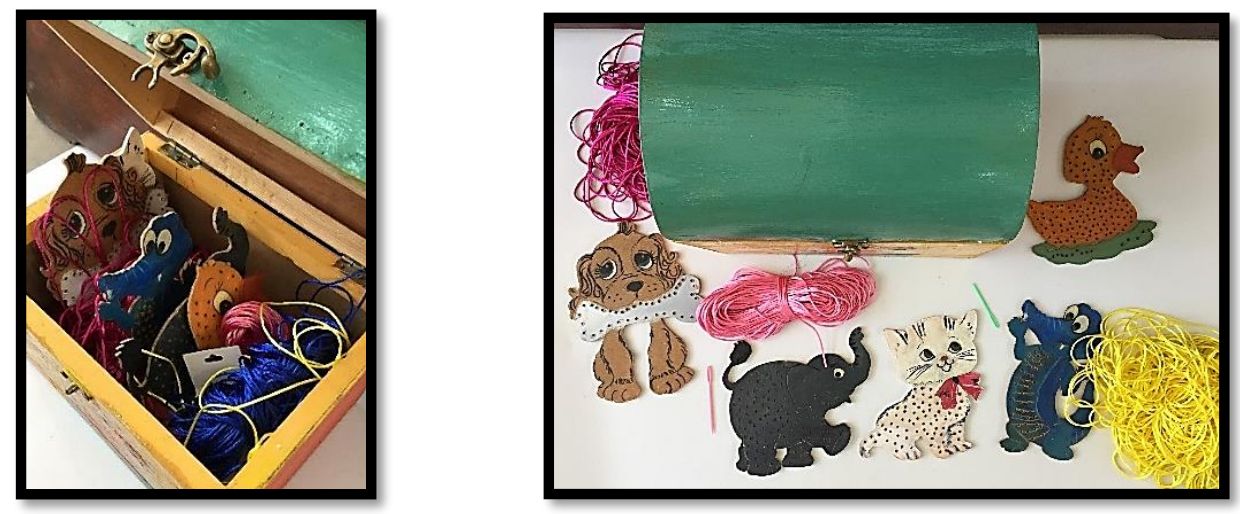


\section{Result and Discussion: Statistical analysis of the results of the practical experiment:}

tools: A questionnaire to measure the suitability of art educational puzzles implemented to achieve the research objectives, a statistical treatment using (IBM SPSS 22).

Statistical treatment used: Calculate scale validity, frequencies and percentages, arithmetic mean, standard deviation.

- An estimated balance was adopted in the evaluation according to the five-fold Likert partition scale:

\begin{tabular}{|c|c|c|}
\hline Response & Weighted average & The general trend \\
\hline Weak & From 1 to 1.80 & Strongly disagree \\
\hline $\begin{array}{c}\text { Acceptable } \\
\text { good }\end{array}$ & 1.81 to 2.60 & Disagree \\
\hline very good & 2.61 to 3.40 & Neutral \\
\hline Excellent & 4.41 to 4.20 & Agree \\
\hline
\end{tabular}

- First, the truth factor according to the alpha coefficient:

\begin{tabular}{|c|c|}
\hline \multicolumn{2}{|c|}{ Reliability Statistics } \\
\hline Cronbach's Alpha & N \\
\hline 0.721 & 25 \\
\hline
\end{tabular}

- Second: Descriptive statistics for each of the questionnaire criteria:

\begin{tabular}{|c|c|c|c|c|c|c|c|c|}
\hline \multirow[b]{2}{*}{ Sub-Criteria for Arbitration } & \multicolumn{5}{|c|}{ Response } & \multirow[b]{2}{*}{$\mathrm{z}$} & \multirow[b]{2}{*}{ 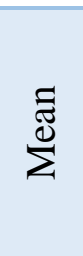 } & \multirow[b]{2}{*}{ D. } \\
\hline & 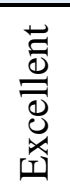 & $\begin{array}{l}\overrightarrow{8} \\
8 \\
00 \\
2 \\
\overrightarrow{0} \\
>\end{array}$ & $\begin{array}{l}\overline{8} \\
8 \\
8\end{array}$ & 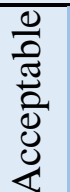 & $\begin{array}{l}\text { है } \\
\frac{\text { है }}{3}\end{array}$ & & & \\
\hline \multicolumn{9}{|c|}{$\begin{array}{l}\text { The first criterion: the basic considerations in implementing art educational puzzles that are } \\
\text { suitable for learners of determination. }\end{array}$} \\
\hline Clarity of goals, idea and instructions for use. & 10 & 0 & 0 & 0 & 0 & 10 & 5 & 0 \\
\hline $\begin{array}{l}\text { A variety of stimuli that fit the target group of the } \\
\text { learner. }\end{array}$ & 5 & 5 & 0 & 0 & 0 & 10 & 4.5 & 0.52705 \\
\hline $\begin{array}{l}\text { It is characterized by ease of performance from the } \\
\text { simple to the most difficult stages. }\end{array}$ & 5 & 4 & 1 & 0 & 0 & 10 & 4.4 & 0.69921 \\
\hline It has attractive shapes, clarity and colors. & 6 & 4 & 0 & 0 & 0 & 10 & 4.6 & 0.5164 \\
\hline Allow repeat play at fault for retry and learning. & 6 & 3 & 1 & 0 & 0 & 10 & 4.5 & 0.70711 \\
\hline $\begin{array}{l}\text { Allows the ability to play alone and in groups to } \\
\text { develop social interaction skills. }\end{array}$ & 6 & 3 & 1 & 0 & 0 & 10 & 4.5 & 0.70711 \\
\hline
\end{tabular}




\begin{tabular}{|c|c|c|c|c|c|c|c|c|}
\hline Helps develop motor skills. & 5 & 4 & 1 & 0 & 0 & 10 & 4.4 & 0.69921 \\
\hline $\begin{array}{l}\text { Helps develop thinking, observation and perception } \\
\text { skills. }\end{array}$ & 8 & 1 & 1 & 0 & 0 & 10 & 4.7 & 0.67495 \\
\hline \multicolumn{9}{|c|}{$\begin{array}{l}\text { The second criterion: the proposed solutions that stimulate the motivation of homeschooling for some } \\
\text { groups of learners of determination. }\end{array}$} \\
\hline $\begin{array}{l}\text { Motivate the learner by giving them enough time to } \\
\text { use it. }\end{array}$ & 7 & 3 & 0 & 0 & 0 & 10 & 4.7 & 0.48305 \\
\hline The content adapted to their cognitive levels. & 5 & 4 & 1 & 0 & 0 & 10 & 4.4 & 0.69921 \\
\hline Instills their concepts of achievement. & 6 & 4 & 0 & 0 & 0 & 10 & 4.6 & 0.5164 \\
\hline $\begin{array}{l}\text { Excites the learners and pushes them to open their } \\
\text { minds and think differently. }\end{array}$ & 8 & 2 & 0 & 0 & 0 & 10 & 4.8 & 0.62146 \\
\hline $\begin{array}{l}\text { Let the Lerner challenge their cognitive levels, } \\
\text { abilities and skills. }\end{array}$ & 6 & 4 & 0 & 0 & 0 & 10 & 4.6 & 0.5164 \\
\hline \multicolumn{9}{|c|}{ Third Criterion: Simple arts' concepts that can be taught to a child of determination. } \\
\hline $\begin{array}{l}\text { The game is characterized by a distinct aesthetic } \\
\text { shape and design. }\end{array}$ & 6 & 4 & 0 & 0 & 0 & 10 & 4.6 & 0.5164 \\
\hline Help to create simplified art knowledge. & 3 & 4 & 3 & 0 & 0 & 10 & 4 & 0.8165 \\
\hline $\begin{array}{l}\text { Process artistic content appropriately for the } \\
\text { purpose. }\end{array}$ & 4 & 6 & 0 & 0 & 0 & 10 & 4.4 & 0.5164 \\
\hline $\begin{array}{l}\text { The artistic idea of the content is distinguished by } \\
\text { originality and distinction. }\end{array}$ & 5 & 4 & 1 & 0 & 0 & 10 & 4.4 & 0.69921 \\
\hline The technique of playing the game is easy and clear. & 6 & 4 & 0 & 0 & 0 & 10 & 4.6 & 0.5164 \\
\hline \multicolumn{9}{|c|}{ Fourth criterion: Providing the learner of determination with some skills related to puzzles. } \\
\hline $\begin{array}{l}\text { Emphasizes the self of the learner as an individual } \\
\text { who can perform valuable and useful work. }\end{array}$ & 5 & 5 & 0 & 0 & 0 & 10 & 4.5 & 0.52705 \\
\hline Learns the learner to respect laws and rules. & 6 & 4 & 0 & 0 & 0 & 10 & 4.6 & 0.5164 \\
\hline $\begin{array}{l}\text { Learns the learner, the scientific method of thinking } \\
\text { and analysis. }\end{array}$ & 6 & 4 & 0 & 0 & 0 & 10 & 4.5 & 0.5164 \\
\hline $\begin{array}{l}\text { The learner gains the ability to attention, } \\
\text { observation accuracy and focus. }\end{array}$ & 4 & 4 & 2 & 0 & 0 & 10 & 4.2 & 0.78881 \\
\hline $\begin{array}{l}\text { Helps to develop memory, perception, imagination } \\
\text { and articulation. }\end{array}$ & 3 & 5 & 2 & 0 & 0 & 10 & 4.1 & 0.73786 \\
\hline Train The different senses of learner. & 5 & 5 & 0 & 0 & 0 & 10 & 4.5 & 0.52705 \\
\hline It develops the learner muscles. & 5 & 5 & 0 & 0 & 0 & 10 & 4.5 & 0.52705 \\
\hline
\end{tabular}




\section{Conclusion:}

- The statistical results of the research were positive in favor of games designed to achieve their educational, artistic and recreational goals.

- Emphasized the principle of motivating and supporting the learner through learning about artistic puzzles.

- Solutions have been proposed to help parents in homeschooling by knowing the importance of puzzles in the educational process for some groups of people of determination.

- Find solutions to how to stimulate the homeschooling for some groups of people of determination.

- Embodied some simple artistic concepts that can be taught to a people of determination in fun artistic educational puzzles.

- Scientifically proven solutions have been proposed to address some of the difficulties faced by families of people of determination at homeschooling in light of the COVID-19 pandemic.

- Ideas were put forward on how to provide a people of determination with some special skills in puzzles, such as the ability to focus and control the muscles of the hand and its synergy with the mind orders.

\section{Recommendations:}

- Pay more attention to groups that make greater efforts to achieve human goals, just as their peers of the same ages, such as the People of Determination group.

- Facilitating difficulties for people of determination in all aspects of life.

- Forming the awareness of citizens in all countries about this group and its needs, taking into account them emotionally and psychologically, accepting them and not rejecting them.

- Paying attention to developing educational strategies and programs for people of determination in all fields based on activities, interaction and play.

- Focusing on the role of art education in stimulating the motivations of learners in all scientific fields, as it is an auxiliary field that raises the level of other scientific subjects. 


\section{References:}

1. Zaid Al-Huwaidi, 2007 AD: Educational Games (Strategy for the Development of Thinking), University Book House, United Arab Emirates.

2. Belqis Ahmed, Mari Tawfiq 2010 AD: (Facilitator in the psychology of play (4th edition, Dar Al-Furqan, Amman.

3. Zaid Al-Huwaidi, 2002 A.D.: The aforementioned reference.

4. Barakat Muhammad Murad: (The Child and Learning by Playing), Ministry of Endowments and Islamic Affairs, No. 524, Arab Republic of Egypt.

5. Ahmed Mohammed Salem 2004: (Educational means and technology), Riyadh, Al-Rasheed Library.

6. Iman Ahmed Hamdi Imam 2015: (The impact of electronic educational games and their role in developing creative thinking for students of the Faculty of Art Education at Helwan University), Emsia magazine.

7. Nahida Al-Dulaimi: (Concepts in Kinetic Education), University of Babylon, Iraq.

8. Gilani Muhammad Bouhamama 2009: (Motivation and learning, the Journal of Education, Qatar National Commission for Education, Culture and Science), Qatar.

9. Maslow, A., \& Lowery, R. (Ed.). (1998). Toward a psychology of being (3rd ed.). New York: Wiley \& Sons.

10. Atkinson.J. (1965). The mainspring of achievement orietntal activity. In JD Grunballs (Ed.) Learning and the educational processes. Skokie.IL. Rond McNally. 